\title{
Diverse sensitivity of cells representing various stages of colon carcinogenesis to increased extracellular zinc: Implications for zinc chemoprevention
}

\author{
STANISLAV JOHN, TOMÁS BRIATKA and EMIL RUDOLF \\ Department of Medical Biology and Genetics, Charles University Faculty of Medicine \\ in Hradec Kralove, Simkova 870, 50038 Hradec Kralove I, Czech Republic
}

Received October 11, 2010; Accepted November 29, 2010

DOI: $10.3892 /$ or.2010.1124

\begin{abstract}
The relationship between zinc intake and risk of colon cancer is widely recognized. Despite reported mechanisms of zinc-mediated effects in colonic cells no information is available on whether zinc is capable of inducing cell death of malignant colonocytes. The present study shows that increased external zinc concentrations inhibit cell growth of three different colon cancer cell lines representing different stages of colon cancer: HCT-116, HT-29 and SW620 cells and induce their death. Of the tested cell lines, SW620 cells proved to be the most sensitive to externally added zinc and this sensitivity was at least partly due to increased levels of intracellular free zinc and the inability to overexpress metallothionein. Further studies into the mechanisms of zinc-induced cell injury and cell death revealed oxidative stress as the most important underlying mechanism activating stress kinase-dependent signaling, perturbation of mitochondria and plasma membrane damage. In addition, observed cell death in individual cell populations was cell line-dependent and variable including cells displaying features of apoptosis, necrosis, autophagy and other mixedtypes. In conclusion, presented results for the first time show variability of responses to zinc in colon cancer at different stages as modeled in vitro and suggest that zinc-induced cell death despite common underlying mechanism(s) might have a variable nature.
\end{abstract}

\section{Introduction}

Zinc is an essential microelement which is involved in many physiological processes in mammalian cells including structural and functional integrity, proliferation, stabilization of

Correspondence to: Dr Emil Rudolf, Department of Medical Biology and Genetics, Charles University Faculty of Medicine in Hradec Kralove, Simkova 870, 50038 Hradec Kralove I, Czech Republic

E-mail: rudolf@lfhk.cuni.cz

Key words: apoptosis, autophagy, zinc, colon cancer, in vitro intracellular environment and protection against various stressors (1). The need for zinc varies individually, with the most sensitive being tissues and organs characterized by a high cell turnover such as skin, bone marrow and intestinal epithelia. Accordingly, it is known that decreased zinc levels in the organism are often associated with various disorders; i.e. growth retardation, delayed wound healing or immune system insufficiency which could be improved by direct zinc supplementation. Moreover, zinc deficiency was documented to predispose for development of several types of tumors including colorectal cancer.

The important role of zinc in colorectal carcinogenesis is documented in vitro as well as in vivo. In zinc-deficient mice, exposure to carcinogenic dimethylhydrazine induced formation of adenomatous polyps and invasive adenocarcinoma (2). Conversely, simultaneous administration of zinc and dimethylhydrazine reduced lipid peroxidation and histopathological changes in colonic epithelia of treated rats as well as improved activity of colonic glutathione S-transferase and superoxide dismutase (3).

Mechanistically, zinc has been reported to inhibit the growth of malignant colonocytes by $\mathrm{G}_{2} / \mathrm{M}$ phase arrest via post-translational regulation of expression of adenomatous polyposis coli (APC) protein, extracellular signal-regulated kinase (ERK)-dependent activation of cell cycle inhibitor p21 and disruption of cell-cell communication as well as microtubule activity $(4,5)$.

Despite these encouraging reports, it is currently not known whether suggested chemopreventive role of zinc extends beyond protection of normal epithelia against carcinogens and, in particular, whether zinc may induce cell death in malignant colonocytes. Thus, in this study we wanted to address this question and investigated the effect of increased extracellular zinc concentrations on cell death in three cell lines representing various stages of colon carcinogenesis.

\section{Materials and methods}

Human colon cancer cell lines HCT-116 (No. 91091005), HT-29 (No. 91072201) and SW620 (No. 87051203) were obtained from ECACC (Porton Down, UK). They were maintained as stationary monolayer cultures in plastic tissueculture dishes (Nunc, Czech Republic). Cells were grown in Dulbecco's modified Eagle's medium (Gibco, Czech Republic), 
supplemented with $10 \%$ fetal bovine serum (Gibco), $100 \mathrm{U} / \mathrm{ml}$ penicillin, and $100 \mu \mathrm{g} / \mathrm{ml}$ streptomycin. The medium was changed every other day, and cells were passaged using $0.25 \%$ trypsin upon reaching confluence of $80 \%$.

The caspase inhibitor, cyclosporine A and c-Jun N-terminal kinase (JNK) inhibitor IX were dissolved in DMSO as stock solutions. Stock solution of N-acetylcysteine (NAC) was prepared in serum-free DMEM. The working concentrations of individual chemicals were achieved by diluting their stock solutions in treatment medium and were as follows: NAC (antioxidant, $1 \mathrm{mM}$, added to cells $24 \mathrm{~h}$ prior to zinc exposure), cyclosporine A (cytochrome c release inhibitor, $5 \mu \mathrm{M}$, supplemented to cells $30 \mathrm{~min}$ before exposure to zinc), IX (JNK inhibitor, $10 \mu \mathrm{M}$, supplemented to cells $30 \mathrm{~min}$ before exposure to zinc), z-VAD-fmk (pancaspase inhibitor, $10 \mu \mathrm{M}$, administered simultaneously with zinc), ABAM (PARP-1specific inhibitor, $20 \mathrm{mM}$, added to cells $2 \mathrm{~h}$ prior to exposure to zinc) and 3-MA (autophagy inhibitor $5 \mathrm{mM}$, supplemented to cells $30 \mathrm{~min}$ prior to zinc exposure.

Zinc sulfate was purchased from Sigma-Aldrich (Prague, Czech Republic). It was dissolved in distilled water as stock solutions of $1 \mathrm{mM}$ and stored. The tested concentrations were prepared by diluting the stock solution in a cultivation medium directly before each experiment. 2'-7'-Dichlorodihydrofluorescein diacetate, JC-1, 4',6-diamidino-2-phenylindole (DAPI), dimethylsulfoxide (DMSO), propidium iodide, $\mathrm{N}$-acetylcysteine (NAC), JNK-specific inhibitor IX, monodansylcadaverine (MDC), specific inhibitor of autophagy 3-methyladenine (3-MA) and $B$-actin were purchased from Sigma-Aldrich. WST-1 (4-[3-(4-iodophenyl)-2-(4-nitrophenyl)2H-5-tetrazolio]-1,3-benzene disulfonate) was purchased from Boehringer Mannheim-Roche (Mannheim, Germany). Primary antibody against MT-II was purchased from Santa Cruz, Inc. (Santa Cruz, CA, USA) and against Beclin-1 from Cell Signaling Technology, Inc. (Danvers, MA, USA). Secondary antibodies were from Alexis Corporation (Lausen, Switzerland). PARP-1-specific inhibitor 3-aminobenzamide (ABAM) was acquired from Calbiochem (EMD Biosciences, Inc., La Jolla, CA, USA). Secondary antibodies for caspase-3 detection were from Molecular Probes, Inc. (Eugene, OR, USA). Monospecific antiserum for the detection of activated caspase-3 was obtained from New England Biolabs, Inc. (Beverly, MA, USA). Newport Green diacetate was from Molecular Probes. All other chemicals were of highest analytical grade.

Cell proliferation assay. All tested cell lines were exposed to normal or zinc-supplemented cultivation medium. At each treatment interval, quantitation of their metabolic activity was carried out using WST-1 assay. WST-1 is a colorimetric assay, which is based on the cleavage of the tetrazolium salt to colored formazan by mitochondrial dehydrogenases in viable cells. Cells at a concentration of 30,000 cells/well in $200 \mu 1$ of DMEM containing $10 \%$ fetal bovine serum were seeded in 96-well microtiter plates, with the first column of wells without cells (blank). The cells were left overnight at $37^{\circ} \mathrm{C}$ in $5 \%$ $\mathrm{CO}_{2}$. Next, cultures were exposed to zinc and at various time points then were rinsed with PBS and $100 \mu 1$ of WST-1 was added. The cells were further incubated for $2 \mathrm{~h}$. The absorbance was recorded at $490 \mathrm{~nm}$ with $650 \mathrm{~nm}$ of reference wavelength by a scanning multiwell spectrophoto-meter (Tecan SpectraFluor Plus, Tecan Austria GmbH, Grödig, Austria). In all cases, the absorbance of the tested substance in medium alone was recorded to determine whether it interfered with the assay. Each solution was tested in sixteen independent wells.

Intracellular free zinc concentration. Cells grown in blackbottom 96-well plates were incubated with Newport Green diacetate $\left(5 \mu \mathrm{M}\right.$ in PBS, dark, $30 \mathrm{~min}$ at $\left.37^{\circ} \mathrm{C}\right)$ and fluorescence intensity was determined by a multiplate reader Tecan SpectraFluor Plus (Tecan Austria GmbH) at 485 and $535 \mathrm{~nm}$, respectively with stable integration time $1000 \mathrm{msec}$ and gain 150 . The results in relative light units (RLU) were obtained from raw data minus reagent blank and expressed as a percentage of controls.

Real-time PCR. Total RNA was isolated from zinc-treated cells at $6,12,24,36,48$ and $72 \mathrm{~h}$ with TRIzol. RNA was resuspended in RNAse-free water, digested with DNAse I and purified using Qiagen columns (Qiagen, Germany). The quality and quantity of obtained RNA was verified by UVVIS spectrophotometry. Real-time RT-PCR was performed with the High pure PCR template preparation kit (Roche, Prague, Czech Repulic) according to the manufacturer's protocol using LightCycler 1.5 (Roche). cDNA was amplified in total 50 cycles with the following conditions: $25 \mathrm{sec}$ denaturation at $94^{\circ} \mathrm{C}(30 \mathrm{sec})$, annealing at $60^{\circ} \mathrm{C}$ (35 sec) and extension at $70^{\circ} \mathrm{C}(40 \mathrm{sec})$. ZnT1 primer sequences were: forward primer CAATACCAGCAACT CCAACGG and reverse primer GCAAGGACCAGCCTC ATAAAC, for Zip4: forward primer CCAGTGTGTGGG ACACGGTAT and reverse primer TGTTCCGACAGT CCATATGCA. The obtained melting curves indicated no primer-dimer formation. $\beta$-actin was used as an internal control for each reaction to ensure equal loading of RNA. Created amplification plots and the threshold cycle were used to calculate the fold change of ZnT1 and Zip4 genes.

ELISA assay of ERK, p38 and JNK activities. Treated and control cells were harvested and collected by centrifugation. Whole cell extracts were prepared by lysis in cell extraction buffer $(10 \mathrm{mM}$ Tris, $100 \mathrm{mM} \mathrm{NaCl}, 1 \mathrm{mM}$ EDTA, $1 \mathrm{mM}$ EGTA, $1 \mathrm{mM} \mathrm{NaF}, 20 \mathrm{mM} \mathrm{Na} \mathrm{P}_{2} \mathrm{O}_{7}, 2 \mathrm{mM} \mathrm{Na} \mathrm{VO}_{4}, 1 \%$ Triton X-100, $10 \%$ glycerol, $0.1 \%$ SDS and $0.5 \%$ deoxycholate with $1 \mathrm{mM}$ protease inhibitor cocktail) for $30 \mathrm{~min}$, on ice, with vortexing at 10 min intervals. ERK, p38 and JNK activities were measured using ELISA kits (SigmaAldrich, St. Louis, MO, USA and Calbiochem, San Diego, CA, USA) specific for total ERK and phospho-ERK (pTpY $\left.{ }^{185 / 187}\right)$, total and phospho-p38 (pTpY ${ }^{180 / 182}$ ) and total and phospho-JNK (pTpY ${ }^{183 / 183}$ ) according to the manufacturer's instructions. The assays were performed in 96-well plate format and samples were read against standard curves obtained from ERK and phospho-ERK, p38 and phospho-p38, JNK and phospho-JNK standards. Results were normalized to micrograms of protein in the cell extract and expressed as the ratio of phospho to total kinase in the same sample. The results of zinc treatment were expressed as percentage of control values. 


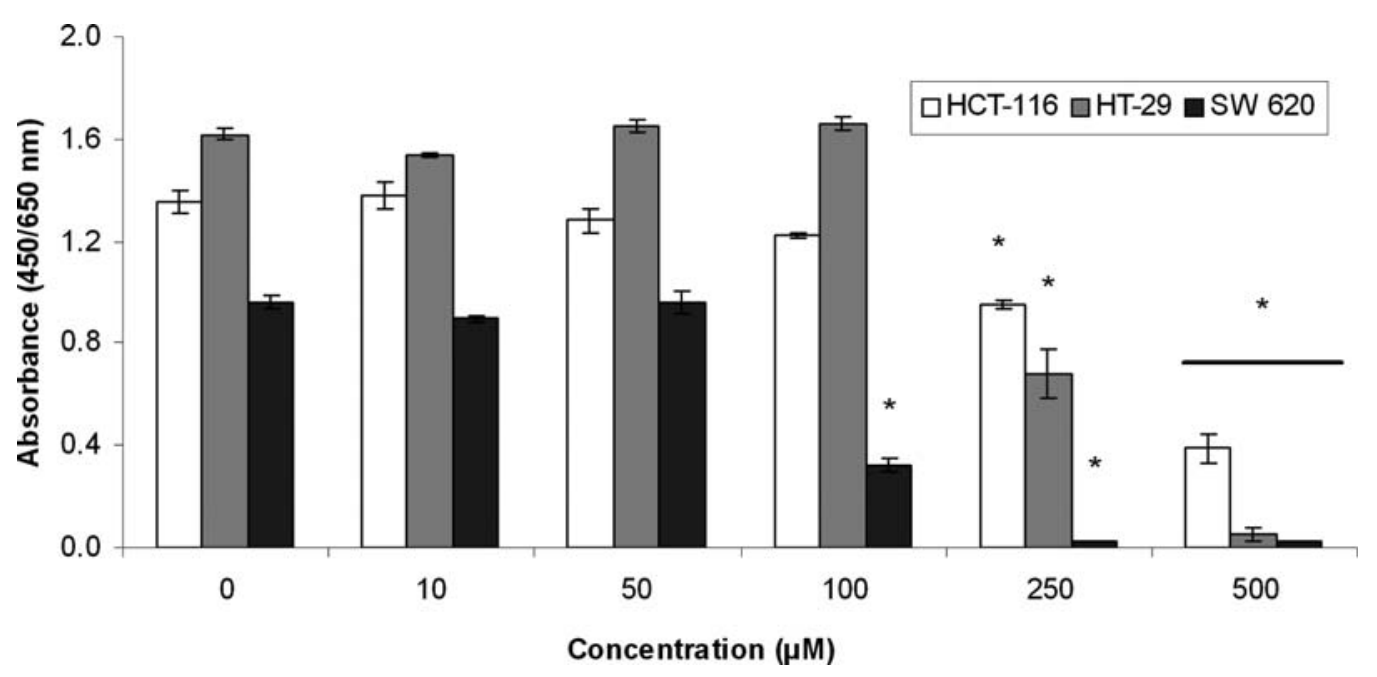

Figure 1. Dose-dependent effects of zinc sulfate (zinc) on proliferation colon cancer cell lines of differing malignant grade, HCT-116, HT-29 and SW620, as measured by WST-1 colorimetric assay during $72 \mathrm{~h}$ of exposure. Cells were treated with a range of zinc concentrations and individual time endpoints were analyzed as described in Materials and methods. Results represent means \pm SD of at least three experiments ${ }^{*} \mathrm{P}<0.05$ compared to untreated control cells with one way-Anova test and Dunnett's post test for multiple comparisons.

Oxidative stress. Generation of hydrogen peroxide and/or hydroxyl radical in treated and control colon cancer cells was monitored by intracellular conversion of 2'-7'-dichlorodihydrofluorescein diacetate (DFCH/DA) into a fluorescent product dichlorofluorescein (DCF). Cells were detached by a cell scraper and collected by centrifugation $(50 \mathrm{x} \mathrm{g}, 5 \mathrm{~min}$, $4^{\circ} \mathrm{C}$; JOUAN M21, Trigon, Prague, Czech Republic). Thereafter, the cells were resuspended in DMEM (pH adjusted to 7.2 ) and $5 \mu \mathrm{mol} / 1 \mathrm{DFCH} / \mathrm{DA}$ was added $\left(5 \mathrm{~min}, 37^{\circ} \mathrm{C}\right)$. Changes in the fluorescence intensity $(485 \mathrm{~nm}$ excitation; $538 \mathrm{~nm}$ emission) were measured by Shimadzu UV-VIS spectrophotometer UV-1601 (Shimadzu Deutschland GmbH, Germany). The data were expressed as a percentage of fluorescence intensity increase per $10^{6}$ cells.

Mitochondrial transmembrane potential $(\Delta \psi m)$ analysis. Cell cultures were seeded into cultivation flasks and allowed to grow overnight. After treatment with SF, cells were rinsed in PBS and stained with $\mathrm{JC}-1$ dye for $15 \mathrm{~min}$ at $37^{\circ} \mathrm{C}$. Mitochondrial membrane potential was assessed by microfluorimetry analysis using Tecan SpectraFluor Plus (Tecan Austria $\mathrm{GmbH}$ ). Mitochondrial transmembrane potential changes were indicated as an increase in fluorescence intensity at $528 \mathrm{~nm}$.

ATP levels. ATP content in colonic cells was measured by ATP bioluminiscent assay kit Sigma-Aldrich (Prague, Czech Republic). ATP content was calculated from a standard curve derived from known concentrations of ATP and was expressed as a percentage of control.

Lactate dehydrogenase ( $L D H$ ) assay. LDH activity was determined at individual time points in the medium of zincexposed colon cancer cell lines. An aliquot $(0.1 \mathrm{ml})$ of each sample was added to a cuvette with $0.2 \mathrm{ml}$ of $2.5 \mathrm{mg} / \mathrm{ml}$ NADH solution and $0.2 \mathrm{ml}$ of sodium pyruvate solution $(1 \mathrm{mg} / \mathrm{ml})$. The total LDH activity was determined after sonication of cells. The enzyme activity was determined spectrophotometrically and the rate of enzyme leakage/min was expressed as percentage of the total LDH activity compared to untreated control cells.

Cell lysis and Western blot analysis. Total cell extracts were prepared by lysis in an ice-cold lysis buffer $(137 \mathrm{mM} \mathrm{NaCl}$, $10 \%$ glycerol, $1 \%$ n-octyl- $\beta$-D-glucopyranoside, $50 \mathrm{mM}$ $\mathrm{NaF}, 20 \mathrm{mM}$ Tris, $1 \mathrm{mM}$ sodium orthovanadate, Complete TMMini). Samples were loaded onto a $12 \%$ SDS/polyacrylamide gel. Each lysate contained equal amount of protein $(30 \mu \mathrm{g})$ as determined by BCA assay. After electrophoresis, proteins were transferred to a PVDF membrane $(100 \mathrm{~V}$, $60 \mathrm{~min}$ ) and incubated at $25^{\circ} \mathrm{C}$ for $1.5 \mathrm{~h}$ with a solution containing 5\% nonfat dry milk, 10 mmol Tris-HCl (pH 8.0), 150 mmol sodium chloride, and 0.1\% Tween-20 (TBST). Membranes were incubated with primary antibodies (antiMT-II, 1:1000; anti-Beclin-1 and anti- 3 -actin, 1:750) at $4^{\circ} \mathrm{C}$ overnight followed by five 6-min washes in TBST. Next, the blots were incubated with secondary peroxidase-conjugated antibodies $\left(1: 1000,1 \mathrm{~h}, 25^{\circ} \mathrm{C}\right)$, washed with TBST and the signal was developed with a chemiluminescence (ECL) detection kit (Boehringer Mannheim-Roche, Basel, Switzerland). Relative quantifications of protein expression were measured using GelQuant Ver 2.7 software (DNR BioImaging Systems, Jerusalem, Israel).

\section{Cell death assays}

Time-lapse videomicroscopy. Cells were seeded into plastic tissue-culture dishes with glass bottom and left for $24 \mathrm{~h}$ in an incubator with $5 \% \mathrm{CO}_{2}$ at $37^{\circ} \mathrm{C}$. The next day, the growth medium was replaced with a medium containing different concentrations of zinc. The tissue-culture dishes were transferred into a time-lapse imaging system BioStation IM (Nikon, Prague, Czech Republic) combining an incubator, a motorized microscope and a cooled CCD camera. Recording was carried out in a multipoint- and multichannel-manner employing various time-lapse modes and upon small as well as high magnifications to allow global as well as detailed view of 
A.

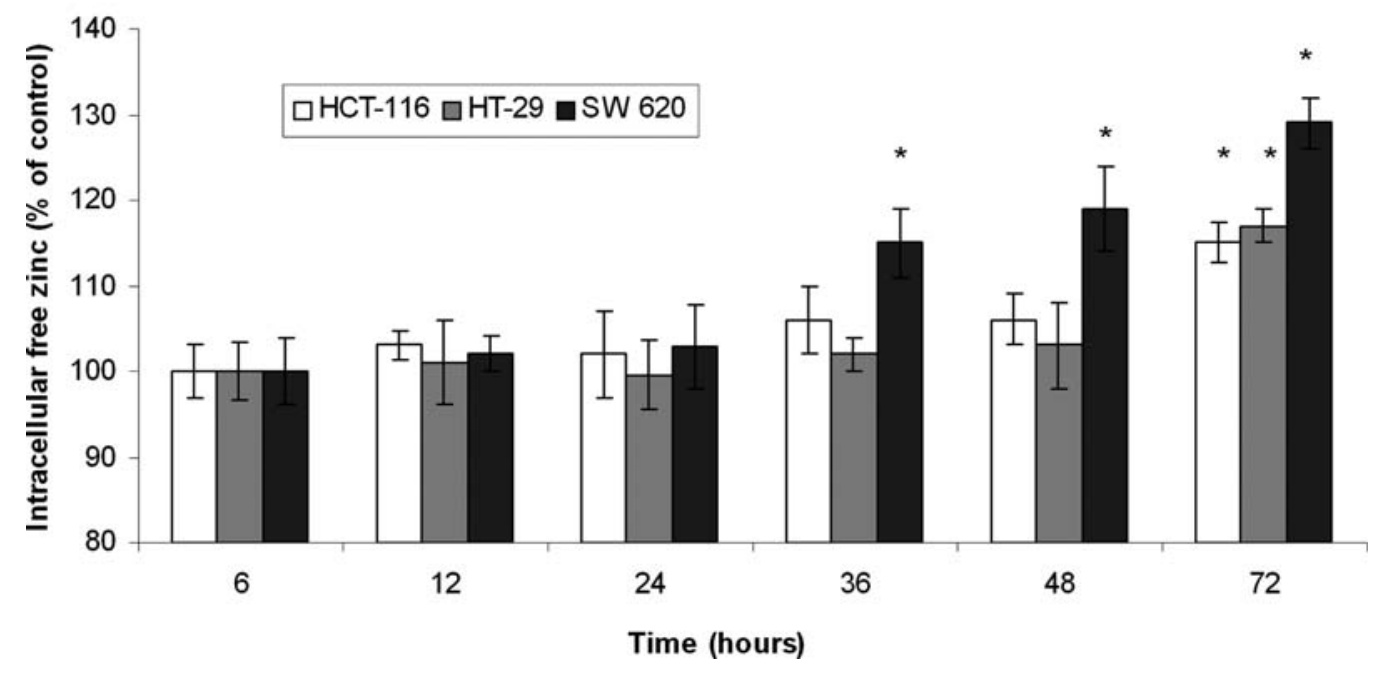

B.

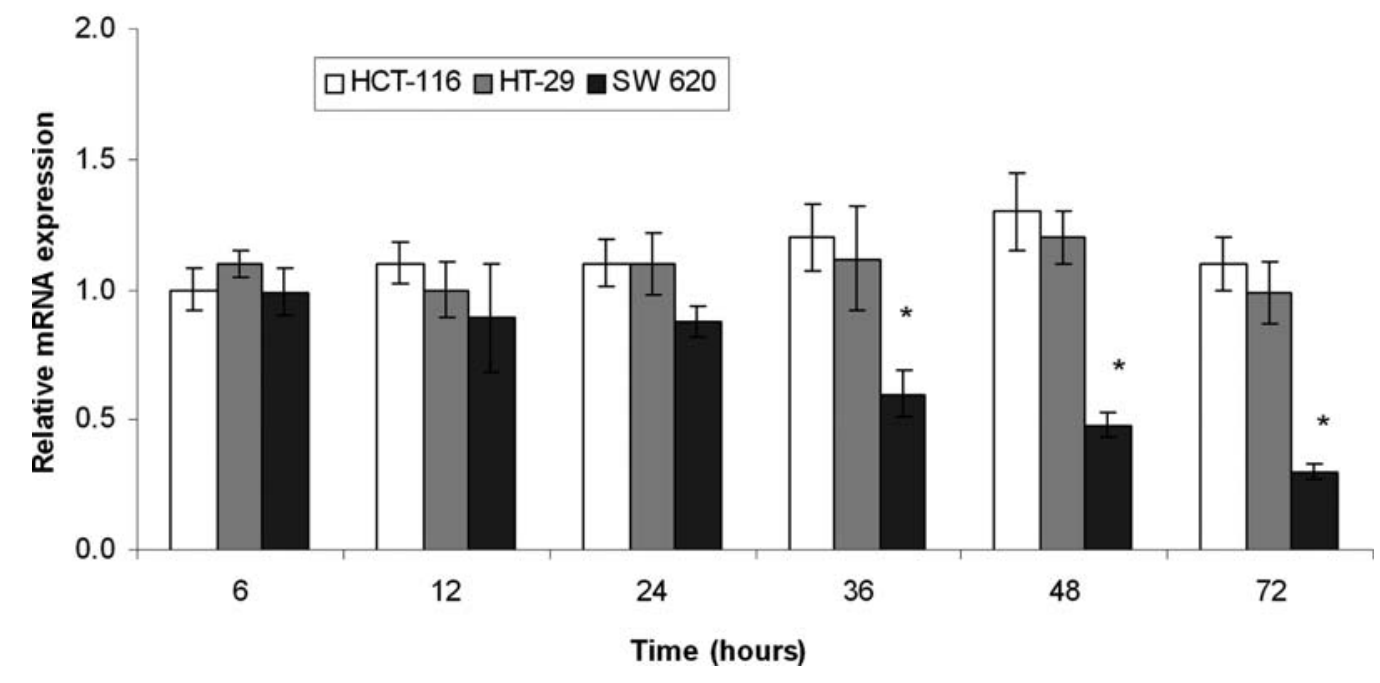

C.

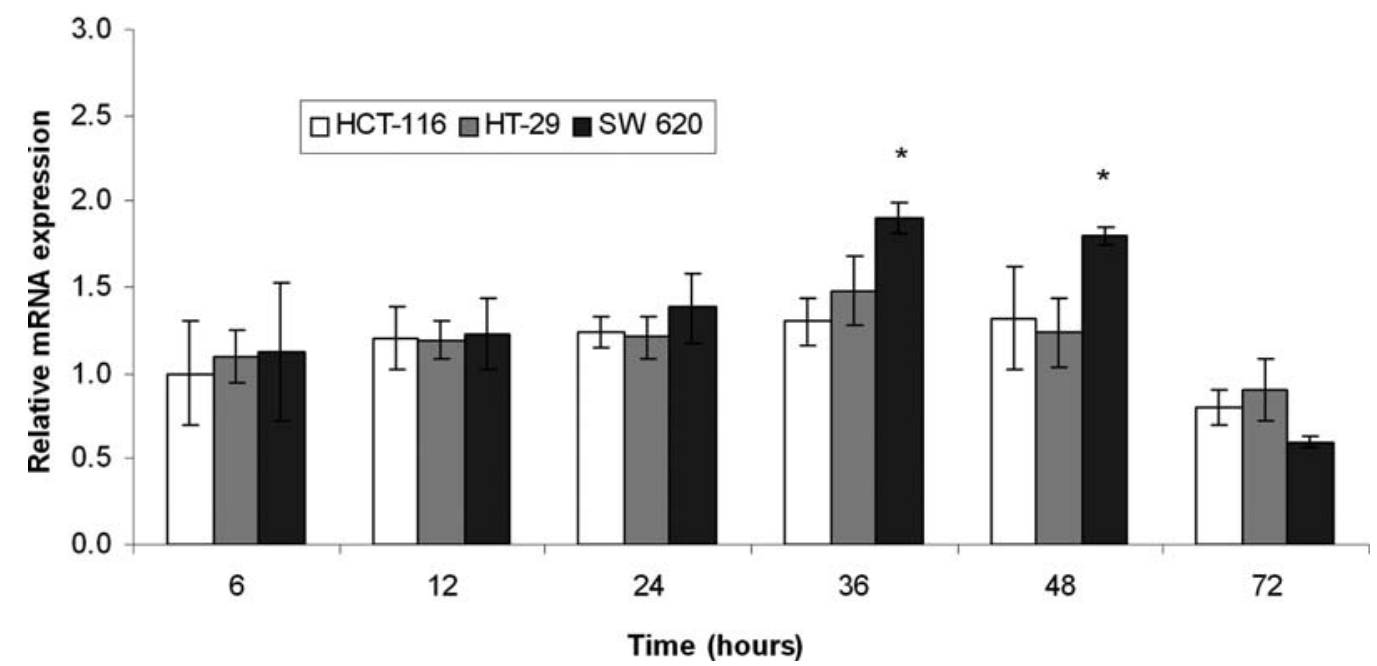

Figure 2. Zinc management in colon cancer cell lines of differing malignant grade, HCT-116, HT-29 and SW620, exposed to $250 \mu \mathrm{M}$ zinc sulfate (zinc) during $72 \mathrm{~h}$. (A) Changes in free intracellular zinc levels as measured by free zinc-specific fluorescent probe Newport Green diacetate $(5 \mu \mathrm{M}$, microfluorimetry). (B) Expression of zinc efflux regulating the ZnT1 transporter as measured by real-time PCR analysis. (C) Expression of zinc influx regulating the ZIP4 transporter as measured by real-time PCR analysis. Treated cells were processed and individual assays were carried out as described in Materials and methods. Results represent the means $\pm \mathrm{SD}$ of at least three independent experiments. ${ }^{*} \mathrm{P}<0.05$ compared to untreated control cells with one way-Anova test and Dunnett's post test for multiple comparisons. 
changes in behavior of treated cell populations. Recorded sequences were subsequently semi-automatically analyzed with the software NIS Elements AR 2.30 (Nikon).

Flow cytometry. Control and zinc-treated colon cancer cells grown in cultivation flasks were harvested with $0.1 \%$ trypsin, rinsed with PBS (5 min) and fixed in $70 \%$ ethanol at $4^{\circ} \mathrm{C}$ for $24 \mathrm{~h}$. After rinsing fixed cells in PBS (5 min), cells were resuspended in a solution containing $0.1 \%$ Triton $\mathrm{X}-100$, $50 \mu \mathrm{g} / \mathrm{ml} \mathrm{RNaseA}$ and $0.5 \mu \mathrm{g} / \mathrm{ml}$ propidium iodide. Following the incubation $\left(30 \mathrm{~min}, 25^{\circ} \mathrm{C}\right.$, dark), the apoptotic, necrotic and other cell populations were determined using a flow cytometer Cell Lab Quanta ${ }^{\mathrm{TM}}$ SC (Beckman Coulter Inc. Brea, CA, USA).

Fluorescence microscopy. Control and zinc-treated cells grown on cover slips were harvested, washed with cold PBS (5 min), fixed with cold methanol $\left(15 \mathrm{~min}, 25^{\circ} \mathrm{C}\right)$ and immunolabeled for caspase-3 with DAPI $\left(10 \mu \mathrm{g} / \mathrm{ml}, 15 \mathrm{~min}, 25^{\circ} \mathrm{C}\right)$ used as a counterstain. Alternatively, grown cells were incubated with $0.05 \mathrm{mM} \mathrm{MDC}$ for $60 \mathrm{~min}$ at $37^{\circ} \mathrm{C}$, fixed in $4 \%$ paraformaldehyde $(15 \mathrm{~min})$, washed with PBS and counterstained with DAPI $\left(10 \mu \mathrm{g} / \mathrm{ml}, 15 \mathrm{~min}, 25^{\circ} \mathrm{C}\right)$. Mounted specimens were examined under a fluorescence microscope Nikon Eclipse E 400 (Nikon) (excitation filter 330-380 nm and emission filter $420 \mathrm{~nm}$ ) equipped with a digital color matrix camera COOL 1300 (VDS, Vosskuhler, Germany). Images were taken using the software NIS Elements AR 2.30 and nuclei of at least 1,000 cells were quantified with subsequent morphometric analysis.

Criteria for determination of type of cell death. Cells were considered apoptotic when at least two independent proapoptotic markers were present; i.e. membrane blebbing (video microscopy), DNA content (flow cytometry), nuclear fragmentation (fluorescence microscopy) and caspase-3 (fluorescence microscopy).

Necrotic cells showed rapid swelling in the absence of membrane blebbing (video microscopy), propidium iodide positivity (flow cytometry), random nuclear morphology (fluorescence microscopy) and low or absent caspase positivity (fluorescence microscopy).

Autophagic cells were determined by their increased expression of Beclin-1 (immunoblotting), MDC positivity (fluorescence microscopy) and presence of vacuoles in the cytoplasm (video microscopy). Cells characterized by other type of cell death displayed mixed features of cell death described above.

Statistics. Statistical analysis was carried out with a statistical program GraphPad Prism 4.0 (GraphPad Software, Inc. San Diego, CA, USA) with one-way Anova test and Dunnett's post test for multiple comparisons. Results were compared with control samples, and the means were considered significant at $\mathrm{P}<0.05$.

\section{Results}

Increased extracellular zinc concentrations have differing antiproliferative effects in colon cancer cells. Extracellular

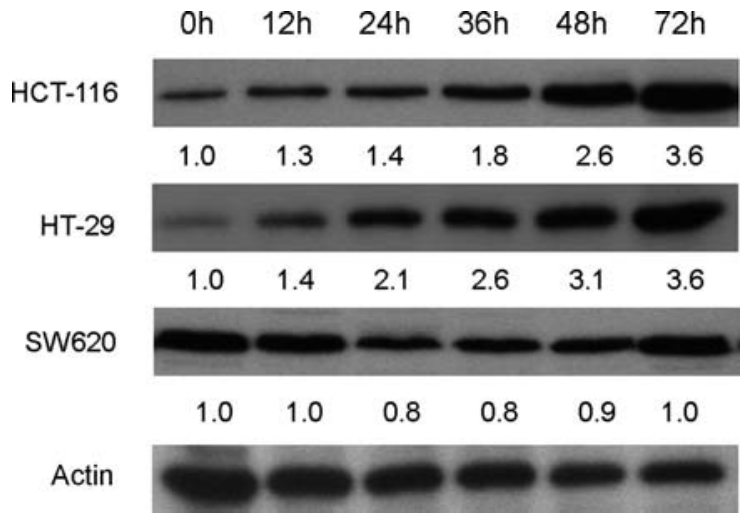

Figure 3. Protein expression of metallothionein MT-IIA in colon cancer cell lines of differing malignant grade, HCT-116, HT-29 and SW620, exposed to $250 \mu \mathrm{M}$ zinc sulfate (zinc) during $72 \mathrm{~h}$ analyzed by immunoblotting. B-actin expression was used to correct protein loading and subsequent band analysis was carried out by GelQuant Ver 2.7 software (DNR Bio-Imaging Systems). Treated cells were processed and individual assays were carried out as described in Materials and methods. Results represent the means \pm SD of at least three independent experiments.

zinc concentrations showed dose-dependent effects on cell growth of studied colon cancer cell lines during $72 \mathrm{~h}$, however, with differing sensitivity among individual cell lines. The most sensitive proved to be metastatic SW620 cells (significant growth inhibition occurring already at $100 \mu \mathrm{M}$ zinc) while HCT-116 and HT-29 cells were more resistant (growth inhibition occurring first at $250 \mu \mathrm{M}$ zinc) (Fig. 1). In order to learn details about effects of externally added zinc, we next conducted experiments with $250 \mu \mathrm{M}$ zinc concentration which proved to inhibit growth and induce cytotoxicity in all studied cell lines.

Zinc homeostasis in colon cancer lines exposed to increased extracellular zinc concentrations. To determine whether observed antiproliferative effects of externally added $250 \mu \mathrm{M}$ zinc in all the examined colon cancer cell lines are due to impaired intracellular zinc homeostasis, firstly changes in intracellular free zinc concentrations were measured. Experimental data show that during $24 \mathrm{~h}$ of treatment no net increase or decrease in free zinc occurred in either of the examined cell lines. Nevertheless, beginning at $36 \mathrm{~h}$ of treatment, a significant elevation of intracellular free zinc was noted in SW620 cells and this trend continued until the end of the experiment (72 h). On the other hand, in HCT-116 and HT-29 cells markedly increased intracellular free zinc levels occurred only at $72 \mathrm{~h}$ of exposure (Fig. 2A).

To gain further insight into the possible mechanisms of unchanged or altered intracellular zinc homeostasis in our experimental model, we next focused on the expression of two key zinc transporters, ZnT1 and Zip4. Time course analysis of mRNA expression of both transporters revealed that zinc efflux regulating ZnT1 was slightly upregulated in HCT-116 and HT-29 cells while in SW620 cells its significant downregulation was observable at later treatment times (36-72 h of exposure, Fig. 2B). The expression of zinc influx transporter Zip4 slightly increased at later treatment periods (HCT-116 and HT-29 cells) while in SW620 cells significant upregulation was noted at 36 and $48 \mathrm{~h}$ of exposure, respectively 


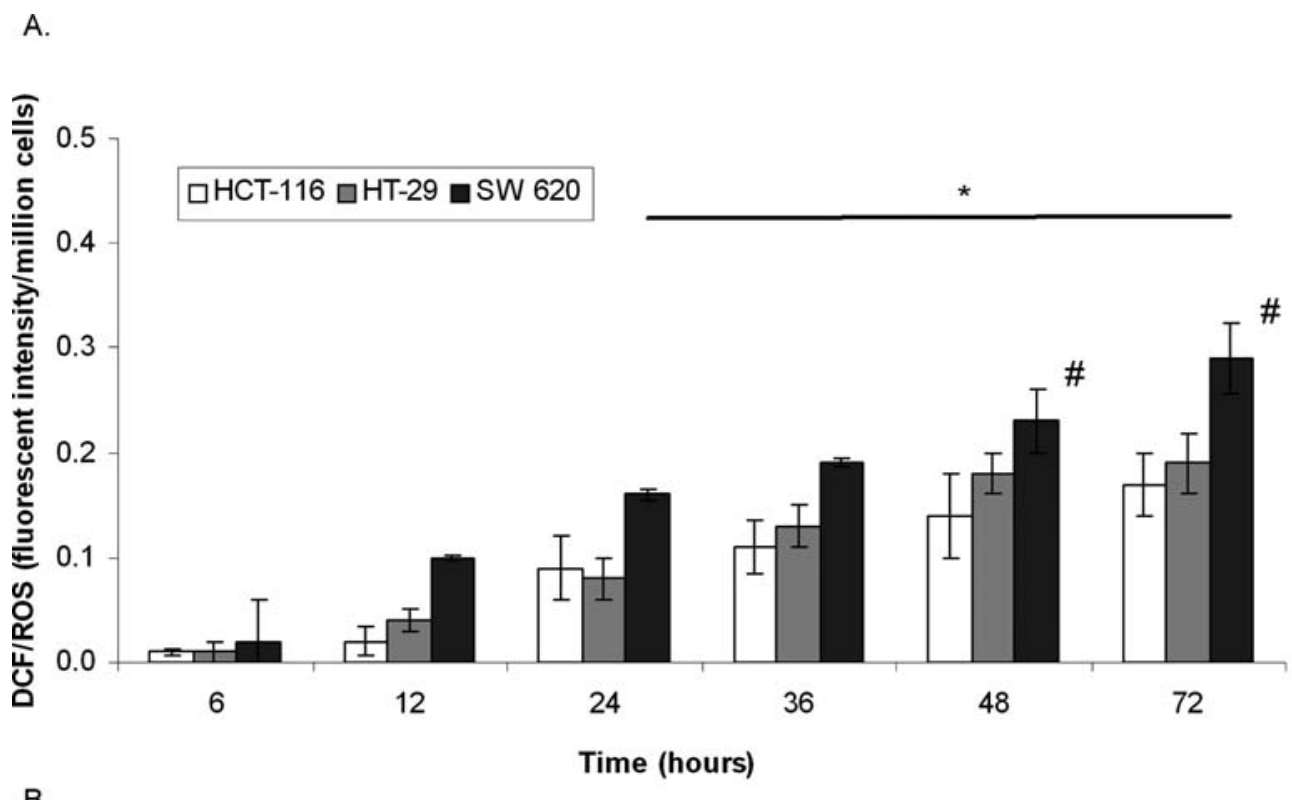

B.

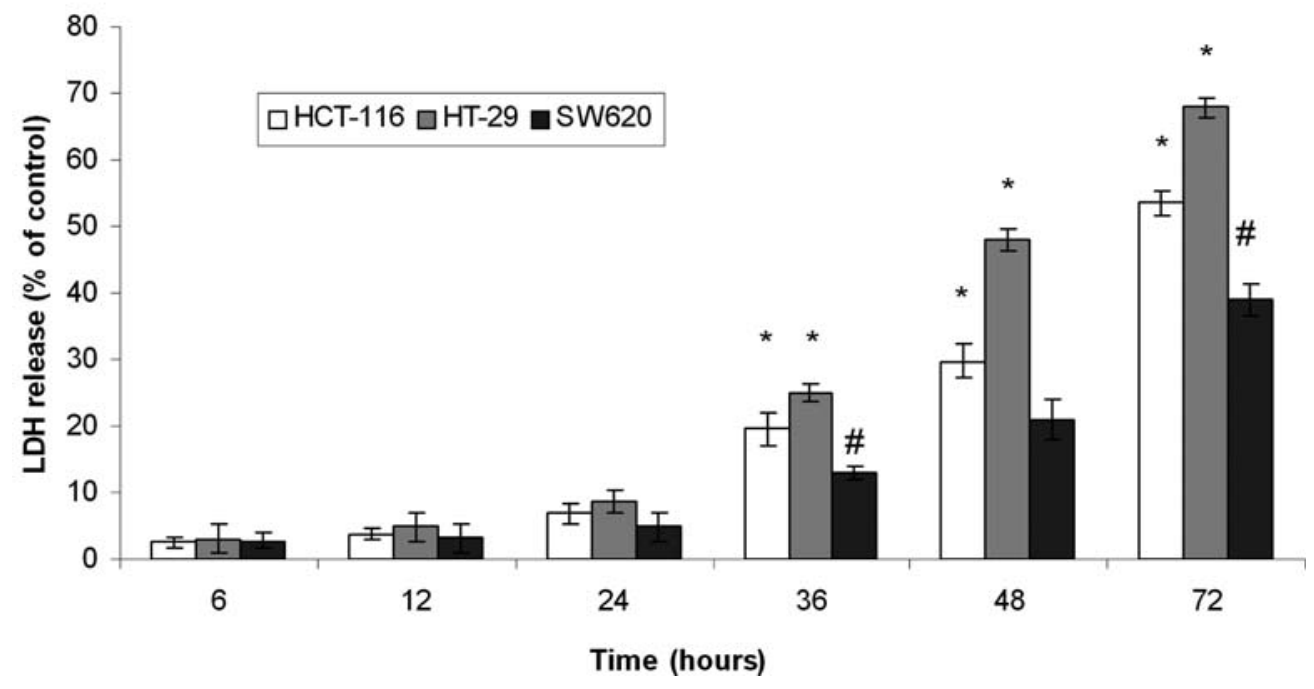

Figure 4. Effects of $250 \mu \mathrm{M}$ zinc sulfate (zinc) on (A) oxidative stress and (B) plasma membrane damage in colon cancer cell lines of differing malignant grade, HCT-116, HT-2 and SW620, during $72 \mathrm{~h}$. Oxidative stress was determined spectrophotometrically by intracellular conversion of 2'-7'-dichlorodihydrofluorescein diacetate (DFCH/DA) into a fluorescent product dichlorofluorescein (DCF). Plasma membrane damage was measured by LDH leakage assay. Results represent the means \pm SD of at least three experiments "P $<0.05$ compared to untreated control cells and \# compared to HCT-116 and HT-29 cells at the same treatment interval with one way-Anova test and Dunnett's post test for multiple comparisons.

(Fig. 2C). Another intracellular free zinc regulator is a family of low molecular weight, cysteine-rich proteins, metallothioneins. Analysis of MT-IIA protein expression in zincexposed cell lines revealed significantly increased abundance of this protein in HCT-116 and HT-29 cells while in SW620 cells its expression remained comparatively the same (Fig. 3).

Stress response of colon cancer cell lines to increased extracellular zinc concentrations. We addressed the question of which type of stress signaling the increased extracellular zinc concentrations induced in exposed colon cancer cells. We employed a series of assays to investigate plasma membrane and energetic status, redox environment and function of key organelles in treated cell lines. Our data show that during
24-36 h of exposure, oxidative stress in all treated cell lines significantly increased and continued rising until the end of experiment. Moreover, the highest levels of this stress were associated with SW620 cells (Fig. 4A). Conversely, plasma membrane damage as measured by LDH release although comparatively increased at the end of the experiment in all examined cell lines was nevertheless markedly lower in SW620 cells (Fig. 4B). Similarly, ATP levels in treated cells decreased more rapidly in HCT-116 and HT-29 cells (Fig. 5A). This decline in cellular ATP content was paralleled by loss of mitochondrial membrane potential which was very rapid and acute in HCT-116 and HT-29 cells and more gradual in SW620 cells (Fig. 5B). Time-course analysis of lysosomal membrane integrity in treated cell lines further revealed 
A.

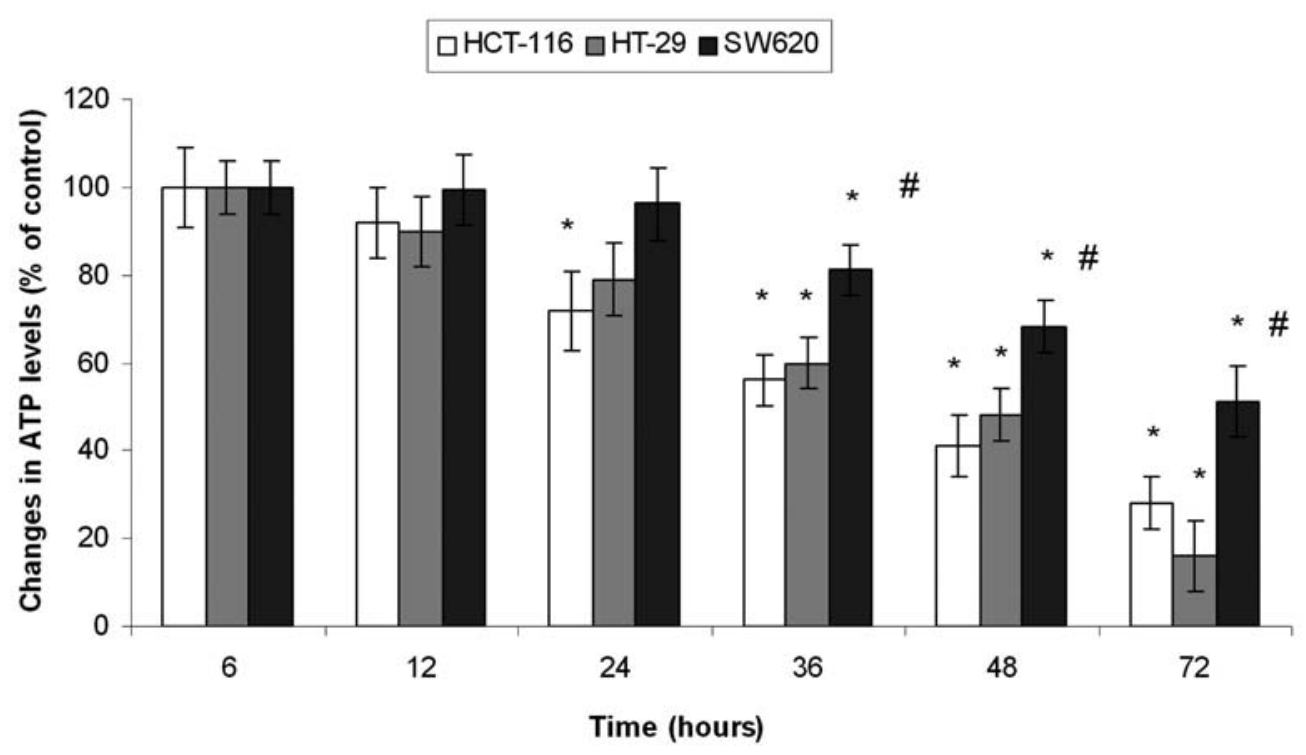

B.

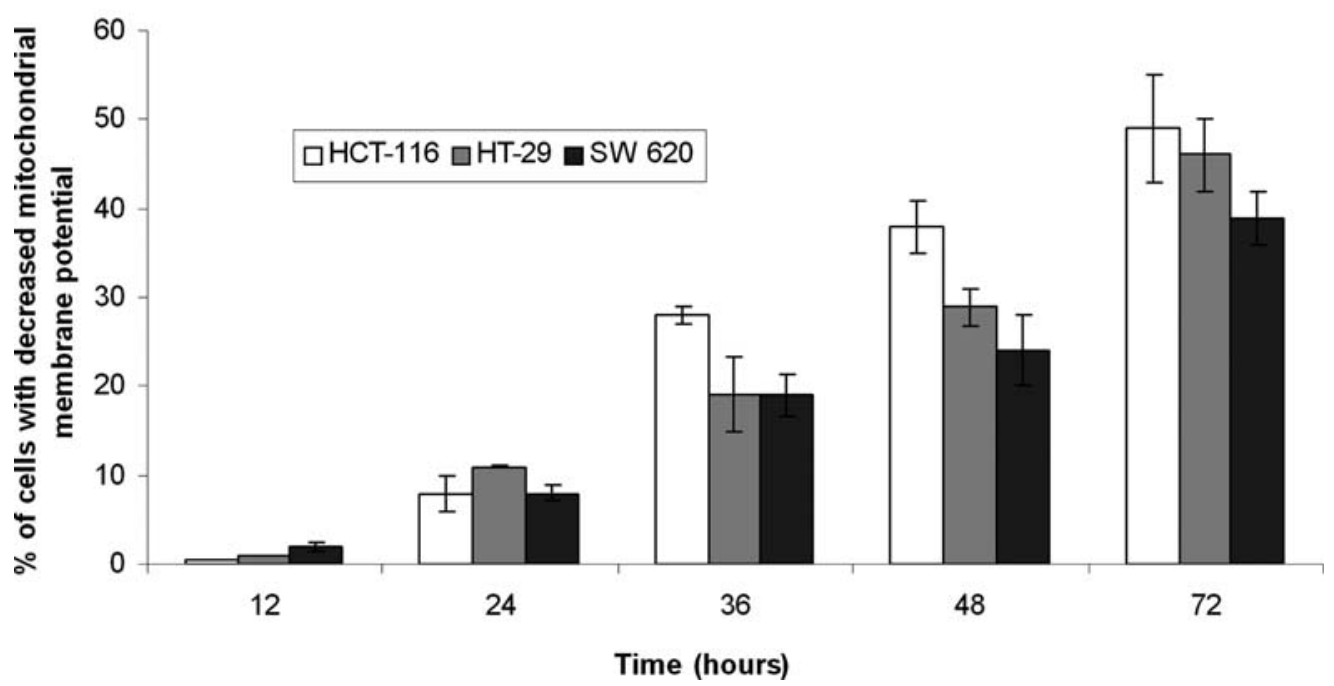

Figure 5. Effects of $250 \mu \mathrm{M}$ zinc sulfate (zinc) on (A) ATP content and (B) mitochondrial membrane potential (MMP) in colon cancer cell lines of differing malignant grade, HCT-116, HT-2 and SW620, during $72 \mathrm{~h}$. ATP content was measured by specilized kit according to the manufacturer's instructions. MMP was determined by microfluorimetric measurement of potential-sensitive JC-1 dye as described in Materials and methods. Results represent means \pm SD of at least three experiments. ${ }^{*} \mathrm{P}<0.05$ compared to untreated control cells and \# compared to HCT-116 and HT-29 cells at the same treatment interval with one wayAnova test and Dunnett's post test for multiple comparisons.

lysosomal content leakage during 24-36 h of treatment, in particular in HCT-116 and SW620 cells (data not shown). At the same treatment interval, changes in expression of mitogenactivated protein kinases also occurred, namely the expression of JNK (JNK - HCT-116 and SW620 cells), p38 (SW620 cells) and ERK (HT-29 cells) (Fig. 6).

Cell death induced by increased extracellular zinc concentrations in colon cancer cell lines. Given the diversity of cell stress signaling observed in colon cancer cell lines exposed to increased external concentrations of zinc, the final endpoints of zinc-induced cytotoxicity, i.e. the mode of cell death was determined with help of several established markers. As demonstrated in Fig. 7, four types of cell demise were simultaneously detected in all treated cells; apoptosis, necrosis, autophagy and other type albeit always in varying proportions in individual cell lines. Unlike necrosis which was predominant type of cell death in HCT-116 and HT-29 cells (constituted $\sim 45-50 \%$ of all dying cells), proportion of apoptotic cells increased with the malignant stage of cell line - HCT-116 (20\%) < HT-29 (28\%) < SW620 (50\%). The same trend was observed in case of autophagy; HCT-116 $(3 \%)<$ HT-29 $(7 \%)<$ SW620 $(10 \%)$ while occurrence of other type of cell death followed a reverse order - HCT-116 $(27 \%)>$ HT $-29(20 \%)>$ SW620 $(0 \%)$.

The effect of pharmacological inhibition of stress signals on the mode of cell death induced by increased extracellular zinc concentrations in colon cancer cell lines. To validate the importance of individual stress signals in execution of cell 


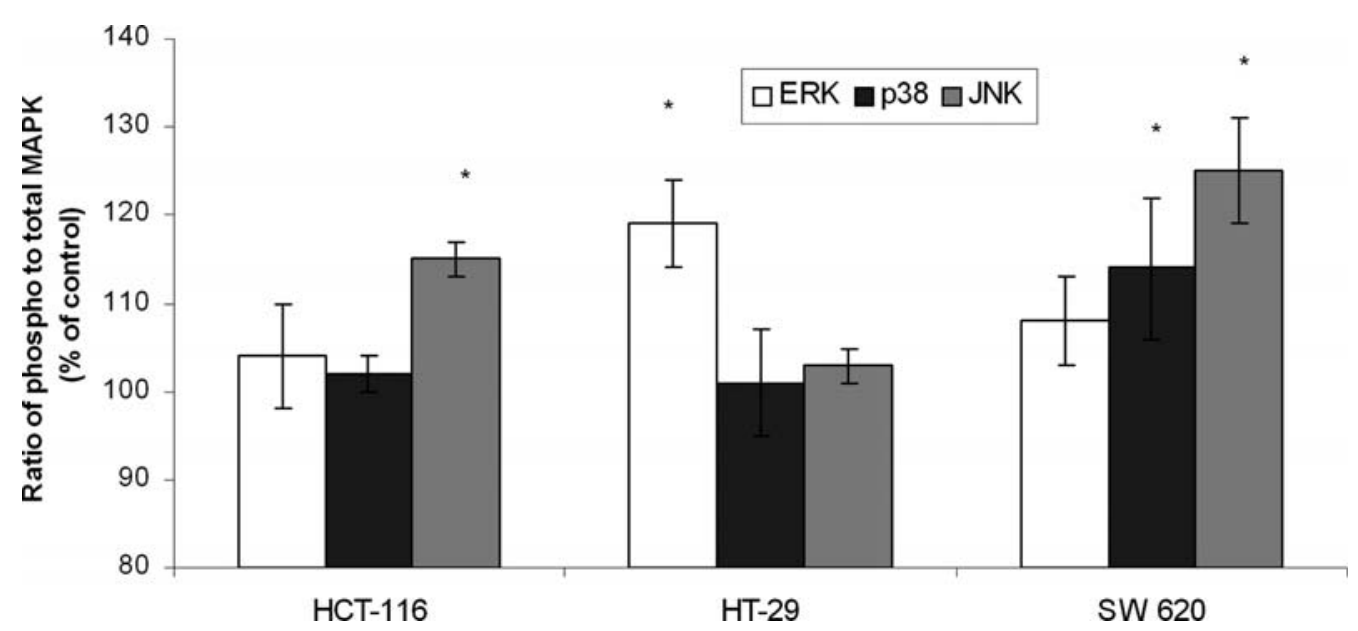

Figure 6. Activation of selected protein kinases, ERK, p38 and JNK, in colon cancer cell lines with differing malignant grade, HCT-116, HT-29 and SW620, exposed to zinc sulfate (zinc) $(250 \mu \mathrm{M})$ during $72 \mathrm{~h}$ of treatment. Cells were incubated and treated as described in Materials and methods. Kinase activities were measured using ELISA kits in 96-well plates (Materials and methods). Results were normalized to micrograms of protein in the cell extract and expressed as the ratio of phosphokinase to total kinase in the same sample. Results represent the means $\pm \mathrm{SD}$ of at least three experiments. ${ }^{*} \mathrm{P}<0.05$ with one way-Anova test and Dunnett's post test for multiple comparisons.

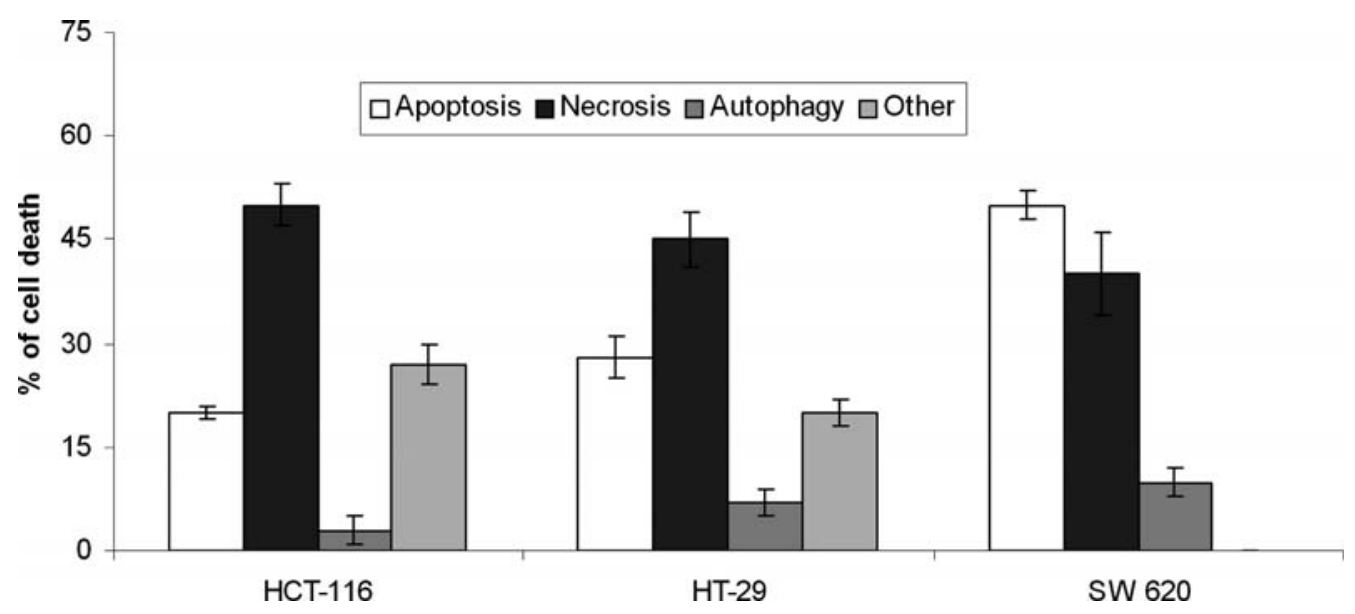

Figure 7. Cell death modes in colon cancer cell lines with differing malignant grade, HCT-116, HT-29 and SW620, treated with zinc sulfate (zinc) (250 $\mu$ M) for $72 \mathrm{~h}$. The criteria for cell death classification included membrane blebbing, DNA content, nuclear fragmentation, caspase-3 positivity, overexpression of Beclin-1 and MDC positivity. Cells were considered apoptotic if being positive in the majority of apoptotic parameters, necrotic cells were positive in necrotic features while cells with autophagy displayed markers for autophagy. Other type of cell death population comprised the cells displaying mixed features of the other three types.

death of the particular type in colon cancer cell lines exposed to elevated extracellular zinc concentrations, we employed several pharmacological inhibitors. The results show that with exception of antioxidant NAC none of the used inhibitors significantly prevented zinc-induced cell death in colon cancer cells (Fig. 8); however, individual agents had a strong effect on stratification of cell death types in individual cell lines. Hence, the inhibition of JNK while insignificant in HCT-116 and HT-29 cells, markedly increased necrosis and apoptosis in SW620 cells. Selective blocking of cytochrome c release by cyclosporine A suppressed apoptosis and increased autophagy (HCT-116 cells) and necrosis (SW620 cells). Antioxidant NAC inhibited necrosis and apoptosis but generally increased autophagy in all studied cell lines. Similarly, PARP-1 inhibitor ABAM greatly suppressed necrosis, increased apoptosis while affecting other types of cell death in all three colon cancer cell lines. Conversely, supplementation of zinc-treated cell with caspase inhibitor z-VAD-fmk suppressed apoptosis and increased necrosis (HCT-116 and HT-29 cells) and autophagy (SW620 cells). Finally, autophagy inhibitor 3-MA proved to increase apoptosis and decrease other type of cell death only in HCT116 cells while in the other cells no significant effect was observed (Fig. 9).

\section{Discussion}

Cancer chemoprevention may be broadly defined as the use of natural or synthetic compounds that have potential to interfere with the development and progression of selected malignancies (6). Chemoprevention of colorectal cancer seems to be perfectly justified as various active compounds may be 


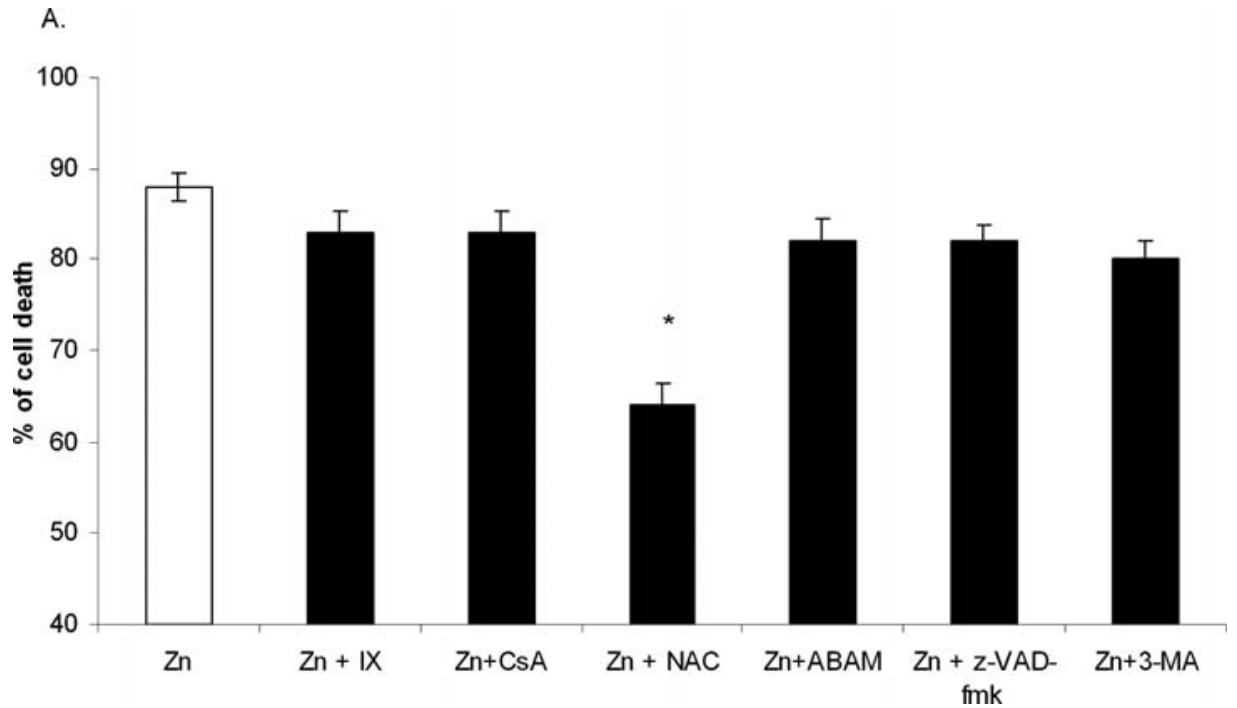

B.

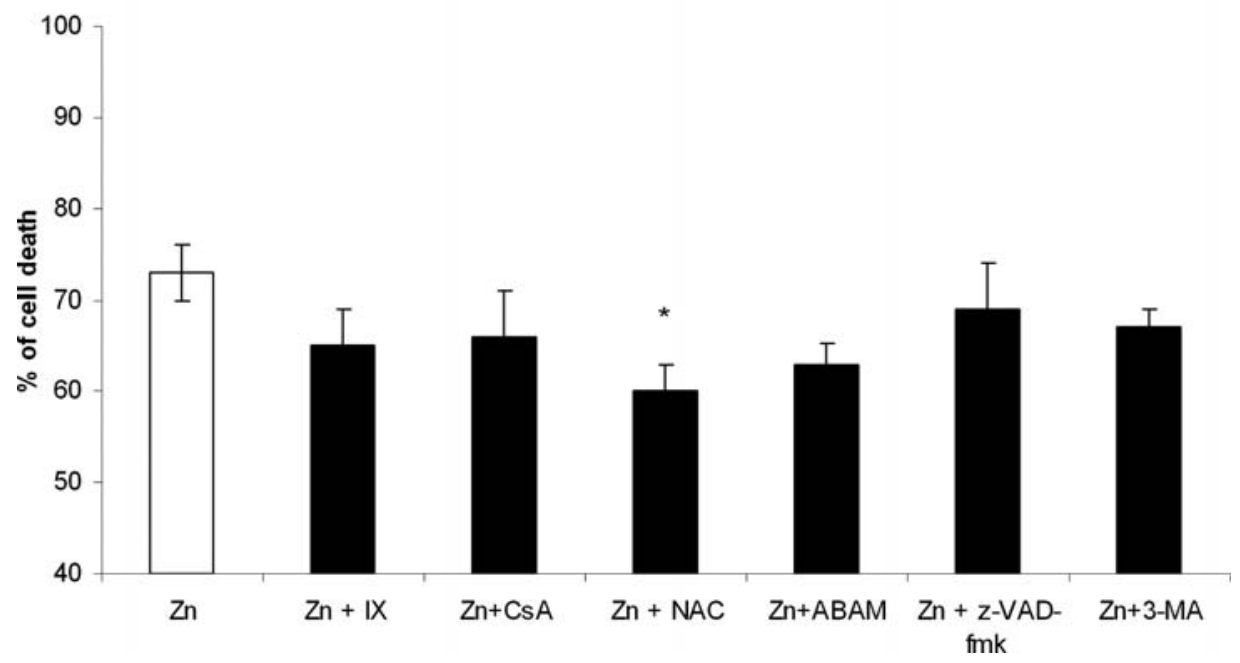

C.

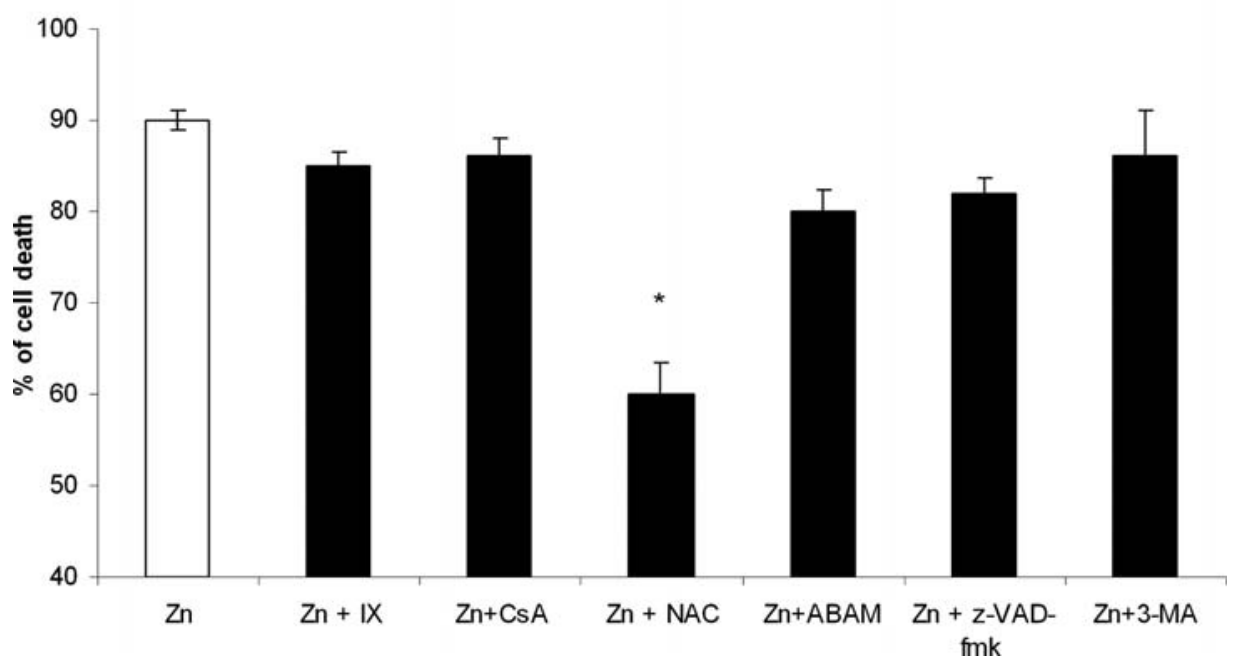

Figure 8. Effects of pharmacological inhibition on $250 \mathrm{nM}$ zinc sulfate (zinc)-induced cell death in colon cancer cell lines with differing malignant grade, HCT-116 (A), HT-29 (B) and SW620 (C), during 72 h. Cells were pretreated with JNK-specific inhibitor (IX), cytochrome c release inhibitor (cyclosporine A), oxidative stress-inhibiting N-acetyl cystein (NAC), PARP-1 inhibitor (ABAM), caspase inhibitor (z-VAD-fmk) and the specific autophagy inhibitor 3-MA prior to zinc exposure and changes in cell death rate were determined as described in Materials and methods. Other results represent the means \pm SD of at least three experiments. ${ }^{*} \mathrm{P}<0.05$ compared to zinc-treated cells with one way-Anova test and Dunnett's post test for multiple comparisons. 
A.

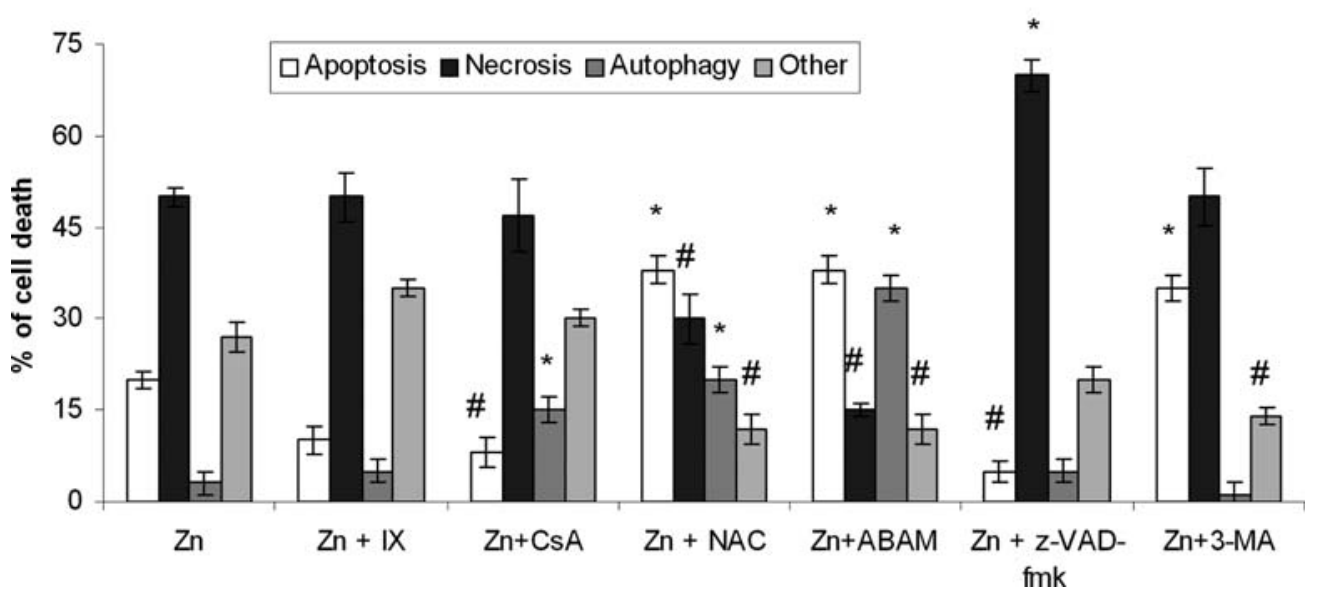

B.

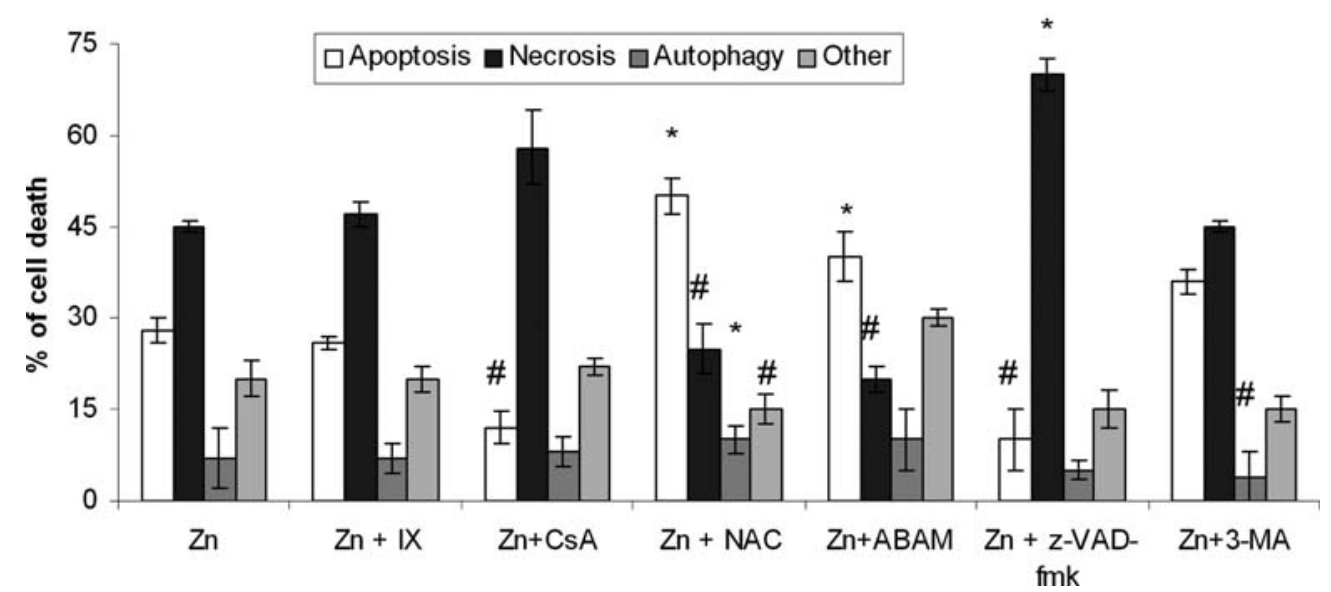

C.

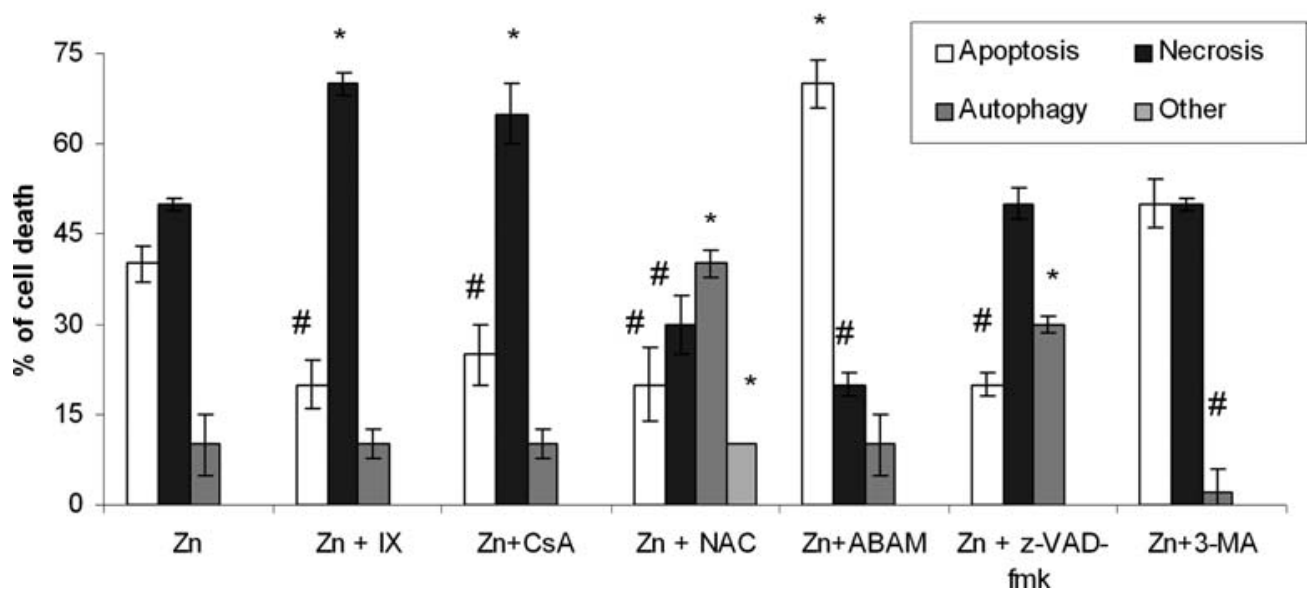

Figure 9. Effects of pharmacological inhibition on $250 \mathrm{nM}$ zinc sulfate (zinc)-induced cell death stratification in colon cancer cell lines with differing malignant grade, HCT-116 (A), HT-29 (B) and SW620 (C), for $72 \mathrm{~h}$. Cells were pretreated with JNK-specific inhibitor (IX), cytochrome c release inhibitor (cyclosporine A), oxidative stress-inhibiting N-acetyl cystein (NAC), PARP-1 inhibitor (ABAM), caspase inhibitor (z-VAD-fmk) and the specific autophagy inhibitor 3-MA prior to zinc exposure and changes in cell death rate were determined as described in Materials and methods. Other results represent the means \pm SD of at least three experiments. *, Higher than in zinc-treated cells; \#, lower than in zinc-treated cells with one way-Anova test and Dunnett's post test for multiple comparisons $(\mathrm{P}<0.05)$.

conveniently administered, they are relatively harmless for humans even at high doses and have direct effect on target tissues.

Zinc plays an important role in maintenance of tissue integrity and function, in particular in systems marked with high cellular turnover such as skin, immune system or digestive system. Acute or chronic zinc deficiency may lead to decreased immunity, poor wound healing, development of inflammation and in some cases it may contribute to the malignant conversion of exposed cells (7-9). 
The relationship between zinc intake and risk of colon cancer has already been suggested before (10-12). Experimental studies suggest that zinc has a beneficial effect against chemically induced colonic preneoplastic progression in rats (3). Zinc induces cell cycle arrest and inhibits proliferation of human malignant colonic cell lines via ERK signaling, APC stabilization and disruption of microtubule stability $(4,13)$. Despite these studies virtually no information is available on whether zinc is capable of inducing cell death of malignant colonocytes and if so which type of cell death and by which mechanism(s). Thus, the purpose of the present study was to investigate the mechanisms of cytotoxicity and cell death-stimulation in three different colon cancer cell lines representing different stages of colon cancer: HCT-116 cells which are p53 positive and non-metastatic, HT-29 nonmetastatic p53 mutant adenocarcinoma cells and metastatic p53 mutant SW620 cells.

Our results firstly suggested that sensitivity of colon cancer cells to externally added zinc for $72 \mathrm{~h}$ of exposure increases with advancing stage of their malignity; i.e. most sensitive proved to be metastatic SW620 cells. Since intracellular zinc management is in particular in colonic cells quite complex and involves various zinc-specific transporters and binders (14-16) which ascertain stable intracellular zinc environment we next checked changes in intracellular free zinc levels. Our data prove that SW620 cells significantly increased free zinc levels beginning at $36 \mathrm{~h}$ of exposure while in HCT-116 and HT-29 cells there were no changes (with exception of the end of experiment) which corresponds to previously published studies (5). In addition, the expression studies of a zinc-efflux transporter ZnT1 and zinc-influx transporter ZIP4 further show their significant dowregulation and upregulation, respectively in SW620 cells only which might explain their greater sensitivity to external zinc concentrations. This hypothesis is further underscored by a failure of SW620 cells to upregulate metallothionein II (MT-II) expression which was seen in HCL-116 and HT-29 cells thus highlighting simultaneously differences in zinc homeostasis management upon different stages of colon cancer development. Nevertheless, it is necessary to mention that despite our discovered differences in the above-mentioned zinc regulators; the entire problem is much more complex since there are numerous zinc-regulating mechanisms whose exhaustive analysis has not been carried out in the present study.

Zinc has been shown to act as a signaling molecule capable of modulating plasma-membrane based pathways and determining cell fate $(17,18)$. In our experimental model, we noted increased activity of JNK (HCT-116, SW620), p38 (SW620) and ERK (HT-29). All kinases were reported to be activated in malignant cells upon their exposure to external zinc $(5,19,20)$ but until now there are no studies mapping their involvement in cells representing different stages of the same malignancy. Thus, this differential activation and involvement of all three kinases clearly reflects variability in colon cancer cells responses to external zinc and highlights the need of further studies into changing patterns of malignant cell behavior.

One of the known mechanisms whereby zinc activates kinase signaling in exposed cells and exerts cytotoxicity is the generation of reactive oxygen species (ROS) (21). In line with this notion, we observed time-dependent elevation in oxidative stress in all colon cancer cell lines. Oxidative stress is known to have multiple targets in exposed cells and indeed our results concur with this fact while demonstrating timedependent increase in membrane damage, ATP and mitochondrial potential loss in zinc-exposed cells. Of note, despite the fact that SW620 cells were more sensitive to zinc than HCT-116 and HT-29 cell lines as seen by cytotoxicity assay as well as by levels of oxidative stress, the very same cells presented less extensive plasma membrane damage and slower ATP as well as mitochondrial potential loss.

Reflecting these differences between individual colon cancer cell lines, cell death as a final endpoint in zinc-exposed cells was analyzed by a several complementing methods. This combinational approach enabled us to analyze in detail cell death mode in individual cells within cell line populations and resulted in identification of basically four types of cell demise; apoptotic, necrotic, autophagic and the type referred by us other mixed-types. Zinc may induce not only single mode of cell death such as apoptosis or necrosis but also both of them simultaneously $(22,23)$. Nevertheless, to the best of our knowledge this is the first study of external zinc inducing several cell death types in colon cancer cell lines representing various stages of colon carcinogenesis.

Moreover, our zinc-induced cell death analyses clearly indicate that unlike necrosis which is predominant form of cell death in all employed cell lines, apoptosis and autophagy involvement increases in more malignant cell lines while other types of cell death decreases. To gain further insight into this complex of cell death phenotypes induced by zinc, we employed a series of pharmacological inhibitors interfering with key cell death signaling molecules. Generally, only antioxidant NAC significantly reduced cell death rate in all three employed cell lines, thus suggesting ROS and oxidative stress as major mechanism of zinc-induced cytotoxicity and cell death in colon cancer cells. Nevertheless, when the effect of individual inhibitors was analyzed in terms of stratification of cell death types in exposed cells, important differences between cell lines were revealed which allowed us to postulate the sequence of events following the exposure to zinc.

In case of HCT-116 cells, zinc induces stress signaling which ultimately involves activation of JNK possibly via oxidative stress, resulting in rapid ATP and mitochondrial membrane potential loss, plasma membrane damage and cell death mostly in the form of necrosis, apoptosis and possibly mixture of both. HT-29 cells exposed to external zinc activate ERK pathway but the following sequence of events resembles the one of HCT-116 cells, with slightly higher presence of autophagy. Conversely, upon exposure to external zinc SW620 cells increase free zinc levels and subsequent stress signaling although involving the same targets (mitochondria, plasma membrane) seems to proceed via apoptosis, necrosis and autophagy.

In conclusion, the present studies show that externally added zinc although at concentrations which exceed those observed in plasma and on luminal surface of enterocytes (24) is cytotoxic to colon cancer cell lines and induced their death. This process fundamentally differs in individual cell lines representing various stages of colon carcinogenesis in 
that that it may involve surface-bound stress signaling or activation of stress pathways due to increased intracellularfree zinc levels. The key phenomenon here is oxidative stress and its diverse targets which may explain the heterogeneous response of malignant colonocytes to zinc and presence of several cell death types. It seems positive, however, that even cells representing advanced metastatic stages of colon cancer are sensitive to zinc and thus further studies comparing and mapping in detail differences in response of a malignant tumor such as colon cancer in its various stages to chemopreventive agents (zinc) are warranted.

\section{Acknowledgements}

This study was supported by GAUK No. 132808 and Ministry of Education Research Project No. MSM 0021620820.

\section{References}

1. MacDonald RS: The role of zinc in growth and cell proliferation. J Nutr 130: S1500-S1508, 2000.

2. Carter JW, Lancaster H, Hardman WE and Cameron IL: Zinc deprivation promotes progression of 1,2-dimethylhydrazineinduced colon tumors but reduces malignant invasion in mice. Nutr Cancer 27: 217-221, 1997

3. Malhotra A, Chadha VD, Nair P and Dhawan DK: Role of zinc in modulating histo-architectural and biochemical alterations during dimethylhydrazine (DMH)-induced rat colon carcinogenesis. J Environ Pathol Toxicol Oncol 28: 351-359, 2009.

4. Jaiswal AS and Narayan S: Zinc stabilizes adenomatous polyposis coli (APC) protein levels and induces cell cycle arrest in colon cancer cells. J Cell Biochem 93: 345-357, 2004.

5. Park KS, Lee NG, Lee KH, Seo JT and Choi KY: The ERK pathway involves positive and negative regulations of HT-29 colorectal cancer cell growth by extracellular zinc. Am J Physiol Gastrointest Liver Physiol 285: G1181-G1188, 2003.

6. De Flora S and Ferguson LR: Overview of mechanisms of cancer chemopreventive agents. Mutat Res 591: 8-15, 2005.

7. Franklin RB and Costello LC: Zinc as an anti-tumor agent in prostate cancer and in other cancers. Arch Biochem Biophys 463: 211-217, 2007.

8. Lansdown ABG, Mirastschijski U, Stubbs N, Scanlon E and Agren MS: Zinc in wound healing: Theoretical, experimental, and clinical aspects. Wound Repair Regen 15: 2-16, 2007.

9. Prasad AS: Zinc and immunity. Mol Cell Biochem 188: 63-69, 1998.
10. Martin Mateo MC and Martin G: Influence of metallic carcinogenesis in lung and colorectal neoplasia. Metals in neoplastic processes. Clin Physiol Biochem 6: 321-326, 1988.

11. Nelson RL: Dietary minerals and colon carcinogenesis. Anticancer Res 7: 259-269, 1987.

12. Song MK, Heng MC, Rolandelli R, Ament ME and Heng MK: Possible link between zinc intake and colon cancer. J Natl Cancer Inst 85: 667-669, 1993.

13. Park KS, Jeon SH, Oh JW and Choi KY: p21Cip/WAF1 activation is an important factor for the ERK pathway dependent anti-proliferation of colorectal cancer cells. Exp Mol Med 36: 557-562, 2004.

14. Azriel-Tamir H, Sharir H, Schwartz B and Hershfinkel M: Extracellular zinc triggers ERK-dependent activation of $\mathrm{Na}^{+} / \mathrm{H}^{+}$ exchange in colonocytes mediated by the zinc-sensing receptor. J Biol Chem 279: 51804-51816, 2004.

15. Lee HH, Prasad AS, Brewer GJ and Owyang C: Zinc absorption in human small intestine. Am J Physiol 256: G87-G91, 1989.

16. Liuzzi JP and Cousins RJ: Mammalian zinc transporters. Ann Rev Nutr 24: 151-172, 2004.

17. Park KS, Ahn Y, Kim JA, Yun MS, Seong BL and Choi KY: Extracellular zinc stimulates ERK-dependent activation of p21Cip/WAF1 and inhibits proliferation of colorectal cancer cells. Br J Pharmacol 137: 597-607, 2002.

18. Wu W, Silbajoris RA, Whang YE, Graves LM, Bromberg PA and Samet JM: p38 and EGF receptor kinase-mediated activation of the phosphatidylinositol 3-kinase/Akt pathway is required for $\mathrm{Zn}^{2+}$-induced cyclooxygenase-2 expression. Am J Physiol Lung Cell Mol Physiol 289: L883-L889, 2005.

19. Eom SJ, Kim EY, Lee JE, Kang HJ, Shim J, Kim SU, Gwag BJ and Choi EJ: $\mathrm{Zn}(2+)$ induces stimulation of the c-Jun N-terminal kinase signaling pathway through phosphoinositide 3-Kinase. Mol Pharmacol 59: 981-986, 2001.

20. Kondoh M, Tasaki E, Araragi S, Takiguchi M, Higashimoto M, Watanabe Y and Sato M: Requirement of caspase and p38MAPK activation in zinc-induced apoptosis in human leukemia HL-60 cells. Eur J Biochem 269: 6204-6211, 2002.

21. Provinciali M, Donnini A, Argentati K, Di Stasio G, Bartozzi B and Bernardini G: Reactive oxygen species modulate $\mathrm{Zn}(2+)-$ induced apoptosis in cancer cells. Free Radic Biol Med 32: 431-445, 2002.

22. Hamatake M, Iguchi K, Hirano $\mathrm{K}$ and Ishida R: Zinc induces mixed types of cell death, necrosis, and apoptosis, in molt-4 cells. J Biochem 128: 933-939, 2000.

23. Kim Y, Kim EY, Gwag BJ, Sohn S and Koh JY: Zinc-induced cortical neuronal death with features of apoptosis and necrosis: mediation by free radicals. Neuroscience 89: 175-182, 1999.

24. Fraker PJ and Telford WG: A reappraisal of the role of zinc in life and death decisions of cells. Proc Soc Exp Biol Med 215: 229-236, 1997. 